\title{
An Analysis of the Components and Measurement of Brand Equity in Residential Areas: A Case Study of Bundang and Ilsan in Korea
}

\author{
Sungki Hong ${ }^{1}$, Jeasun Lee ${ }^{2}$ and Brian Hong Sok Kim ${ }^{3}$ \\ ${ }^{1}$ Graduate Student, Department of Urban Planning and Engineering, Yonsei University, Korea \\ ${ }^{2}$ Professor, Department of Urban Planning and Engineering, Yonsei University, Korea \\ ${ }^{3}$ Professor, Agricultural Economics and Rural Development, Seoul National University, Korea
}

\begin{abstract}
City and place marketing is highly recognized in urban planning and management. As one of the brand marketing resources, the brand and brand equity of residential areas draws considerable attention. No attempt was made in previous studies to explore the components of brand equity, causality of components and measurement strategies of brand equity in residential areas. This study establishes a conceptual model to estimate the brand equity in residential areas and to identify a method for evaluating brand equity components with their relationships using modification of general goods and services through a brand equity evaluation model. The results indicate that brand awareness and brand personality have a direct influence on brand equity, while perceived quality has an indirect influence due to intermediation by reputation. In addition, brand awareness, perceived quality, and reputation in Bundang are higher than those in Ilsan.
\end{abstract}

Keywords: brand equity; brand equity components; residential area

\section{Introduction}

As a result of Korea's legitimate municipal system which began in 1995 , most of the municipal governments placed greater importance on promoting local brands and stimulating local economies (Kim 2005; Oh, 2005; Kim 2006; Kang, 2006; Byeon, 2009). Promoting the local brand of a city becomes an important and effective strategy for better city management and local economic development.

A number of studies have explored the brand equity strategy cases of the private industry and housing market (Boyle and Kiel, 2001; Pagourtzi et al., 2003; Jung, 2009; Lee, 2011). Hedonic pricing methods are commonly used to demonstrate housing market valuation with respect to the changes in the characteristics of property. However, only a few empirical studies have investigated the competitiveness effect by different forms of brand equity in largescale residential developments. Han and Lim (2003) pointed out that the brand strategies of local residential areas should adopt different approaches than the brand strategies used by companies. The conventional

*Contact Author: Jeasun Lee, Professor, Department of Urban Planning \& Engineering, College of Engineering,

Yonsei University, 262 Seongsanno, Seodaemun-gu,

Seoul, 120-749 Korea

Tel: +82-2-2123-5894 Fax: +82-2-393-6298

E-mail: jeasunlee@yonsei.ac.kr

(Received April 18, 2011 ; accepted January 23, 2012) promotion strategies of a local residential area brand with respect to existing impressions, facilities, environments and cultures are difficult to adopt and practice.

Two methods were used to measure brand equity in previous studies. The first method applies the financial value of brand equity to the business franchise and measures the outcome of customer-based brand equity (Aaker and David, 1991; Farquhar et al., 1991; Simon and Sullivan, 1992). This accounting method is effectively developed and tested for the appraisal of brand name equity value. The second method evaluates the responses of the customer with respect to the brand name (Keller, 1993; Schocker et al., 1994).

In this study, the authors will focus on the first method, the financial value of brand equity, to identify and measure the important components of brand equity in a residential area. There are four main objectives in this study: 1) verify theoretical applicability of the previous models, 2) identify the components conventionally developed in previous studies, used to measure the product and service brand equity, 3) develop a model for brand equity measurement in residential areas, and 4) investigate correlations among the brand equity components and their effects on equity establishment based on empirical results.

2. Methods

2.1 Procedure

New towns located on the outskirts of Seoul in 
Table 1. General Characteristics of the Study Area

\begin{tabular}{|c|c|c|c|}
\hline \multicolumn{2}{|r|}{ Name } & Bundang & Ilsan \\
\hline \multicolumn{2}{|c|}{ Characteristics } & $\begin{array}{l}\text { - Construction of a self-sufficient new town by } \\
\text { CBD for the Gangnam region in Seoul and the } \\
\text { Metropolitan Area } \\
\text { - Development of a fresh outskirt residential area } \\
\text { for the middle-class }\end{array}$ & $\begin{array}{l}\text { - Formation of a garden city with artistic } \\
\text { and cultural facilities } \\
\text { - Formation of the central city of the } \\
\text { western Metropolitan Area with self- } \\
\text { sufficiency } \\
\text { - Formation of an advance base for the }\end{array}$ \\
\hline \multirow{6}{*}{ Area (ha) } & Location & $\begin{array}{l}\text { - } 25 \mathrm{~km} \text { away from Seoul to the South East } \\
\text { - Seoungnam City, Gyounggido }\end{array}$ & $\begin{array}{l}\text { - 20km away from Seoul to the North West } \\
\text { - Goyang City, Gyounggido }\end{array}$ \\
\hline & Total & 1,894 & 1,573 \\
\hline & Residential Area & 614.1 & 528.3 \\
\hline & Commercial Area & 85.5 & 45.7 \\
\hline & Business Area & 72.5 & 106.3 \\
\hline & Infra Structure & 380.4 & 304.7 \\
\hline Popul & ttion (Thousand) & 390 & 276 \\
\hline House & hold (Thousand) & 97.5 & 69 \\
\hline
\end{tabular}

Korea are considered as the study areas. The authors considered two conditions for the site selection and to measure brand equity. The first condition is that the area should have a high level of awareness and specific impression regarding recognition by the general public. The second condition is that the selected areas should share similar physical, geological and functional characteristics. Based on these two conditions, the Bundang and Ilsan areas are selected for the analysis in this study. These areas are among the initial major new towns in the Seoul Metropolitan Area (SMA). Table 1. summarizes the general characteristics of these two study areas.

1) Sample and Data Collection

The survey was conducted using online panelists from the Gallup Korea institution. The samples are selected among 80,000 panelists and proportionally stratified to consider gender, age and location (4 zones in Seoul). The selected samples are between the ages of 20 and 59 who are currently residing in Seoul with similar distance to the study areas. They are assumed to visit the study areas a number of times.

After pre-test and modification of the questionnaires, the survey was conducted online from October 28, 2011 to October 30, 2011. Of the 535 survey responses collected, 512 responses have valid data for the analysis.

2) Analysis Method

First, to investigate the general characteristics of the samples, a frequency analysis and a descriptive analysis were conducted. A t-test was used to analyze the significance of the difference in the evaluation results for each investigation item of the study areas. Secondly, an exploratory factor analysis and a confirmatory factor analysis were carried out to verify the reliability and validity of the measurement variables. The reliability was analyzed using the Cronbach's Alpha values to examine the internal reliability of the extracted factors. A correlation analysis was also performed to investigate the correlations among the input variables. Thirdly, structural equation modeling analysis was carried out using AMOS 5 to verify the study model. Two-way ANOVA was utilized to verify the significance of the scored class difference in the brand equity between Bundang and Ilsan.

\subsection{Research Frame}

\subsubsection{Conceptual Model and Research Questions}

To estimate the brand equity in residential areas and to identify the components for brand equity evaluation, a conceptual model was established, as shown in Fig.1. This conceptual model was designed following the results of Aaker (1996) and Lee (2006), in an effort to measure the brand equity of residential areas and investigate the effects of the components. The components, which are the sources of brand equity, were divided into brand recognition, brand personality (impression), and perceived quality (Aaker, 1996).

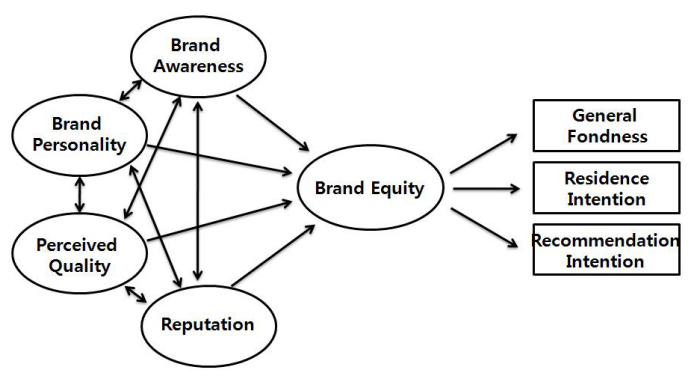

Fig.1. A Conceptual Model for Research

Brand loyalty was not included in the category of brand equity, because it was recognized as a dependent variable of the brand equity. This was done because the brand equity components of awareness and impression influence brand loyalty. Acker (1991) and Yoo and Donthu (2000) reported that the brand loyalty is a core of brand equity and is partially influenced by impressions. Lee (2006) added that the reputation could be influenced by advertisements and/or recommendations by experts and other local elements, such as high price and involvement of residential products.

Therefore, the research questions the authors seek to 
answer are as follows:

1. Establishment of a model for the measurement of residential area brand equity: Is it possible to measure the brand equity of the special product, which in this case is a residential area, using conventional brand equity measurement models?

2. Investigation of the effects of the individual components: In what ways and to what extent do the individual components influence the formation of brand equity?

3. Measurement and comparison of brand equity: How different are the types of brand equity of Bundang and Ilsan as measured by an established model? Is there a significant difference in the variables of residential location, age and income level of the residents?

\subsection{Measurement Details of Brand Equity}

According to Asker (1991), brand equity is a multidimensional concept that consists of brand awareness, perceived quality, brand association, and other proprietary assets. For the purpose of this study, brand equity consists of brand awareness, brand personality, perceived quality, reputation and brand loyalty. Three items for brand awareness were adopted from measures developed by Yoo and Donthu (2000) and Aaker (2001). Twelve items for brand personality were drawn from previous studies and modified by adding the items used by Kim (2005). Twenty perceived quality items were drawn from the Gyeonggi Research Institute (2001). Three reputation items were drawn from the Gyoungnam Development Institute (2005) and Lee (2006). Three brand loyalty items were adopted from measures developed by Yoo et al. (2000). Table 2. presents a detailed summary of the multiple item scales.

1) Brand Awareness

Awareness is divided into top of mind, unaided, and aided awareness. Top of mind awareness of the participant is assessed with open questions. Unaided recall is then measured with additional questions. The measurement of understanding is replaced by the measurement of knowledge about two study areas with respect to the residential environment. Brand awareness is then modified into first impression, brand remembrances and brand understanding on a five-point Likert scale.

2) Brand Personality

The recognition of competing brands by consumers is different depending on their brand personality. In this respect, a new measurement method is needed in urban planning to measure the brand personality. The Brand Personality Scale (BPS) used by Aaker (2001) and measurement items used by Kim (2005) are employed, with some modification, for the brand personality measurement in this paper. Twelve items on a sevenpoint Likert scale represent brand personality ranging from 1 (strongly disagree) to 7 (strongly agree).

\section{3) Perceived Quality}

In the previous studies, detailed items were derived and measured for the perceived quality. A preliminary study is conducted for the assessment of satisfaction and quality of life in a new town residential area. The items to represent perceived quality are measured on a seven-point Likert scale.

4) Reputation

Information leading to the reputation of a residential area is an important factor concerning housing purchase and residential area choice. The source of information may be obtained via the mass media, advertisement, personal (friend) recommendation, and expert recommendation. Therefore, reputation is included as one of the brand equity components and measured on a seven-point Likert scale.

5) Brand Loyalty

Brand loyalty is an attitudinal and behavioral component and can be defined as the level of general fondness for an area. It represents the intention of residents and their consistent recommendation to others. A seven-point Likert scale was used for measurement of the three items representing brand loyalty.

\section{Results and Discussions \\ 3.1 Descriptive statistics}

Frequent and descriptive analysis is performed to investigate the general characteristic of the samples from 512 survey respondents. A t-test is used to observe the significance of the evaluation results for each investigation item between Bundang and Ilsan.

The respondents' initial brand image as a new town in SMA for Bundang is $49.6 \%$ and for Ilsan $20.9 \%$. This shows that there is a large difference in brand image between these two areas. The total brand unaided recall from added four instances for Bundang is $77.0 \%$ and for Ilsan $72.9 \%$, which shows similar recall rates. The awareness level of residential areas showed that the positive response rate of Bundang is $39.5 \%$ (an average rating of 3.16) and Ilsan 36.1\% (an average rate of 3.12), which also shows similar evaluation results.

As for the measurement of general fondness in the overall impression, the brand awareness of the respondents showed that the positive response rate for Bundang is 59.6\% (an average rating of 4.77) and for Ilsan $52.5 \%$ (an average rating of 4.57 ), which showed that Bundang has a more positive impression than Ilsan. As for perceived quality, Bundang showed a relatively higher rate of positive evaluation than Ilsan. The total of nine items is positively evaluated for Bundang with a ratio of $60 \%$ or higher, while only four items for Ilsan are positively evaluated with a ratio of $60 \%$ or higher. The evaluation scores for the educational environment, living environment, and housing price are higher in Bundang than Ilsan. However, Ilsan is evaluated more positively than 
Table 2. Variables and Measurement

\begin{tabular}{|c|c|c|c|}
\hline \multicolumn{2}{|r|}{ Dimension } & Items & \multirow{2}{*}{$\begin{array}{l}\text { Scale } \\
\text { Free Association } \\
\text { Free Association } \\
\text { Likert (5 Points) } \\
\end{array}$} \\
\hline & Brand Awareness & $\begin{array}{l}\text { First Impression } \\
\text { Brand Remembrance } \\
\text { Brand Understanding (Knowledge on Residential Area) }\end{array}$ & \\
\hline & Brand Personality & $\begin{array}{l}\text { Enjoyable } \\
\text { Vibrant } \\
\text { Modern } \\
\text { Bright and Clean } \\
\text { International } \\
\text { Luxurious } \\
\text { Friendly } \\
\text { Beautiful } \\
\text { Abundant } \\
\text { Feeling Proud } \\
\text { Individual } \\
\text { Feeling Safe }\end{array}$ & Likert (7 Points) \\
\hline $\begin{array}{c}\text { Perceived } \\
\text { quality }\end{array}$ & $\begin{array}{l}\text { Transportation Environment } \\
\text { Education Environment } \\
\text { Living Environment } \\
\text { Natural Environment } \\
\text { Culture and Welfare Environment }\end{array}$ & $\begin{array}{l}\text { Using Public Transportation in the Inner City } \\
\text { Using Public Transportation between Cities } \\
\text { Traffic Movement within the City } \\
\text { Traffic Movement between Cities } \\
\text { Elementary and Middle school } \\
\text { High School } \\
\text { Private Education Institute } \\
\text { Residential Facilities } \\
\text { Wholesale } \\
\text { Commercial Facilities } \\
\text { Air Conditioning } \\
\text { Green Space } \\
\text { Performance Facilities } \\
\text { Social Welfare Facilities } \\
\text { Leisure Facilities } \\
\text { General Hospital } \\
\text { Library } \\
\text { Sport Facilities } \\
\text { Current Housing Price } \\
\text { Future Investment Value }\end{array}$ & Likert (7 Points) \\
\hline & Reputation & \begin{tabular}{|l|} 
Reputation from Mass Media \\
Acquaintance's Recommendation \\
Profession's Recommendation \\
\end{tabular} & Likert (7 Points) \\
\hline & Brand Loyalty & $\begin{array}{l}\text { General Fondness } \\
\text { Residence Intention } \\
\text { Recommendation Intention } \\
\end{array}$ & Likert (7 Points) \\
\hline Soc & o-demographic characteristics & $\begin{array}{l}\text { Gender } \\
\text { Age } \\
\text { Address } \\
\text { Marriage } \\
\text { Occupation } \\
\text { Income } \\
\text { Housing Type } \\
\text { Housing Ownership }\end{array}$ & \\
\hline
\end{tabular}

Bundang concerning its natural, cultural and social welfare environment. This result showed that these two areas make very different impressions.

The reputation for Bundang is significantly higher than Ilsan based on three evaluation items: reputation from the mass media, recommendation by friends, and recommendation by construction company professionals or real estate agents.

Bundang also has higher brand loyalty than Ilsan. $62.9 \%$ of Seoul residents rated Bundang positively and $53.7 \%$ rated Ilsan positively. Also while $54.9 \%$ of the respondents desired to live in Bundang in the future, only $45.1 \%$ wanted to live in Ilsan. As for another behavioral variable of brand loyalty, the intent to 
recommend Bundang to others is $53.5 \%$ and for Ilsan $44.1 \%$, which indicates that there is a higher brand loyalty in Bundang than Ilsan.

\subsection{Factor analysis and reliability test}

The exploratory factor analysis and confirmative factor analysis are carried out with SPSS V.12.0 to identity the primary factors and to verify the reliability and validity of the measurement. Cronbach's Alpha is used to estimate the consistency of respondents' response to the items. The reliability was analyzed using Cronbach's Alpha values to examine the internal reliability of the extracted factors. Moreover, an analysis was conducted to investigate the correlations among the input variables.

1) Exploratory factor analysis

An exploratory analysis evaluates the feasibility of the constitution of the questionnaire items. The varimax otation of principal component analysis is used, and the inner consistency is verified using Cronbach's Alpha values.

(1) Brand personality

The first factor, named 'smartness,' consists of 'individual,' 'feeling proud,' 'friendly,' 'feeling safe,' 'beautiful,' and 'international.' The second factor, named 'dignity,' consists of 'modern,' 'bright and clean,' 'luxurious,' and 'abundant.' The third factor, named 'dynamics,' is composed of 'enjoyable' and 'vibrant.' 'Feeling proud' and 'abundant' in the second factor of the individual measurement variable are eliminated because the factor accumulation values of both exceeded 0.4 .

(2) Perceived quality

The first factor consists of 11 items related to the educational and living environment. The second factor is composed of five items related to the natural, cultural and welfare environment. The third factor consists of four items for the transportation environment. Applying the same criterion as in the brand personality, a total of eight individual variables are eliminated. After eliminating the factors, the individual factors are named 'living,' 'nature' and 'transportation.'

(3) Reputation and brand loyalty

Three individual variables measured with respect to the reputation are combined into one factor. The factor of brand loyalty, composed of general fondness, residence intention and recommendation intention, showed the greater descriptive power of the variance.

2) Confirmative factor analysis

The confirmative factor analysis examines whether the items extracted by the exploratory factor analysis and the reliability analysis are appropriate to measure the brand equity of residential areas. The brand awareness is excluded from the analysis, because it includes two measurement variables and the path of the factors is well verified using four variables that showed sufficiently high GFIs (Goodness of Fit Index). The Adjusted GFI (AGFI) values are also sufficiently high, except brand loyalty.

3) Correlation analysis among the variables

The overall characteristics of the variables and the strength of the relationships among the main variables are investigated using Pearson's correlation analysis. The results showed that the variables are correlated because a positive correlation coefficient exceeding the significance level was found between all of the variables.

\subsection{Path analysis for the verification of the research} subject

In order to verify the conceptual model, a path analysis is conducted using the Amos 5.0. Structural equation model analysis is also carried out using AMOS 5.0 to verify the study model. Two-way ANOVA was performed to verify the significance of the scored hierarchical difference in brand equity between Bundang and Ilsan.

1) First and second research objectives verification

The GFI and path coefficient verification showed that brand awareness, brand personality and reputation have a direct effect on the formation of brand equity. The perceived quality, on the other hand, did not have a direct effect on brand equity. Thus, a modified model, based on the assumption that perceived quality can affect brand equity formation indirectly through the reputation, is prepared and re-verification is carried out. A cause-and-effect relationship analysis with the modified model showed that the path coefficient

Table 3. Result of the Exploratory Factor Analysis for Brand Personality

\begin{tabular}{|c|c|c|c|c|c|c|}
\hline \multicolumn{2}{|c|}{ Factor } & Variable & $\begin{array}{l}\text { Factor } \\
\text { Loading }\end{array}$ & $\begin{array}{l}\text { Eigen } \\
\text {-value }\end{array}$ & $\begin{array}{c}\text { Communality } \\
\text { (Accumulated Ratio) }\end{array}$ & Cronbach's Alpha \\
\hline \multirow{3}{*}{$\begin{array}{c}\text { Brand } \\
\text { Personality }\end{array}$} & Smartness & $\begin{array}{l}\text { Individual } \\
\text { Feeling proud (eliminated) } \\
\text { Friendly } \\
\text { Feeling safe } \\
\text { Beautiful } \\
\text { International }\end{array}$ & $\begin{array}{l}.772 \\
.698 \\
.694 \\
.684 \\
.677 \\
.642\end{array}$ & 3.807 & $\begin{array}{c}31.73 \\
(31.73)\end{array}$ & .875 \\
\hline & Dignity & $\begin{array}{l}\text { Modern } \\
\text { Bright and clean } \\
\text { Luxurious } \\
\text { Abundant (eliminated) }\end{array}$ & $\begin{array}{l}.794 \\
.789 \\
.729 \\
.642\end{array}$ & 3.000 & $\begin{array}{c}25.00 \\
(56.73)\end{array}$ & .863 \\
\hline & Dynamics & $\begin{array}{l}\text { Enjoyable } \\
\text { Vibrant }\end{array}$ & $\begin{array}{l}.807 \\
.793\end{array}$ & 2.209 & $\begin{array}{c}18.41 \\
(75.14)\end{array}$ & .862 \\
\hline
\end{tabular}


Table 4. Result of the Exploratory Factor Analysis for Perceived Quality

\begin{tabular}{|c|c|c|c|c|c|c|}
\hline \multicolumn{2}{|r|}{ Factor } & Variable & $\begin{array}{c}\text { Factor } \\
\text { Loading }\end{array}$ & $\begin{array}{l}\text { Eigen } \\
\text {-value }\end{array}$ & $\begin{array}{c}\text { Communality } \\
\text { (Accumulated Ratio) }\end{array}$ & Cronbach's Alpha \\
\hline \multirow[t]{3}{*}{$\begin{array}{l}\text { Perceived } \\
\text { Quality }\end{array}$} & Living & $\begin{array}{l}\text { Private educational institutes } \\
\text { High schools } \\
\text { Elementary and middle school } \\
\text { Wholesale } \\
\text { Commercial facilities (eliminated) } \\
\text { Residential facilities (eliminated) } \\
\text { General hospital } \\
\text { Library (eliminated) } \\
\text { Current housing price } \\
\text { Public sport facilities (eliminated) } \\
\text { Future investment value }\end{array}$ & $\begin{array}{l}.832 \\
.806 \\
.770 \\
.719 \\
.704 \\
.671 \\
.661 \\
.648 \\
.647 \\
.631 \\
.599\end{array}$ & 6.507 & $32.54(32.54)$ & .922 \\
\hline & Nature & $\begin{array}{l}\text { Green space } \\
\text { Air environment } \\
\text { Leisure facilities (eliminated)) } \\
\text { Performance facilities (eliminated) } \\
\text { Social welfare facilities (eliminated) }\end{array}$ & $\begin{array}{l}.805 \\
.789 \\
.721 \\
.643 \\
.604\end{array}$ & 4.168 & $\begin{array}{c}20.84 \\
(53.38)\end{array}$ & .848 \\
\hline & Transportation & $\begin{array}{l}\text { Inter-city public transportation } \\
\text { Inter-city traffic flow } \\
\text { Intra-city public transportation } \\
\text { Traffic flow within the city }\end{array}$ & $\begin{array}{l}.822 \\
.803 \\
.760 \\
.704\end{array}$ & 3.478 & $\begin{array}{c}17.39 \\
(70.77)\end{array}$ & .880 \\
\hline
\end{tabular}

Table 5. Result of the Exploratory Factor Analysis for Reputation and Brand Loyalty

\begin{tabular}{|c|c|c|c|c|c|}
\hline Factor & Variable & $\begin{array}{l}\text { Factor } \\
\text { Loading }\end{array}$ & $\begin{array}{l}\text { Eigen } \\
\text {-value }\end{array}$ & $\begin{array}{c}\text { Communality } \\
\text { (Accumulated Ratio) }\end{array}$ & Cronbach's Alpha \\
\hline Reputation & $\begin{array}{l}\text { Expert's recommendation } \\
\text { Friend's recommendation } \\
\text { Reputation from mass media }\end{array}$ & $\begin{array}{l}.934 \\
.911 \\
.861\end{array}$ & 2.443 & $\begin{array}{c}81.4 \\
(81.4)\end{array}$ & .885 \\
\hline Brand Loyalty & $\begin{array}{l}\text { General fondness } \\
\text { Residence intention } \\
\text { Recommendation intention }\end{array}$ & $\begin{array}{l}.928 \\
.944 \\
.950\end{array}$ & 2.655 & $\begin{array}{l}88.5 \\
(88.5)\end{array}$ & .934 \\
\hline
\end{tabular}

and critical ratio of perceived quality is 0.829 and 8.206 , respectively. Both of these values exceed the reference value of 1.960. Therefore, it is accepted that modified hypothesis of perceived quality has a significantly positive effect on brand equity formation and reputation. Brand awareness and brand personality, on the other hand, do not have a significant influence on reputation and have only a direct effect on brand equity. Based on these analyses, a model to measure residential brand equity is established, as shown in Fig.2., which is the first objective of this study.

2) Third research objective verification

In order to utilize the measurements obtained from the survey questionnaire in the established brand equity measurement model, the following standardization procedures are conducted. First, among the four brand equity components, the scores for brand personality, perceived quality and reputation measured on the basis of a seven-point Likert scale are converted to points by setting the full score at 100 . Second, brand awareness is converted to points with the full score set at 5. It is adjusted with reference to the brand knowledge measured on the basis of a five-point Likert scale. These points are then re-converted into points with a full score of 100. The standardized mean scores are then calculated by applying the weight to each factor value and converted to the points based on the full score of 100.

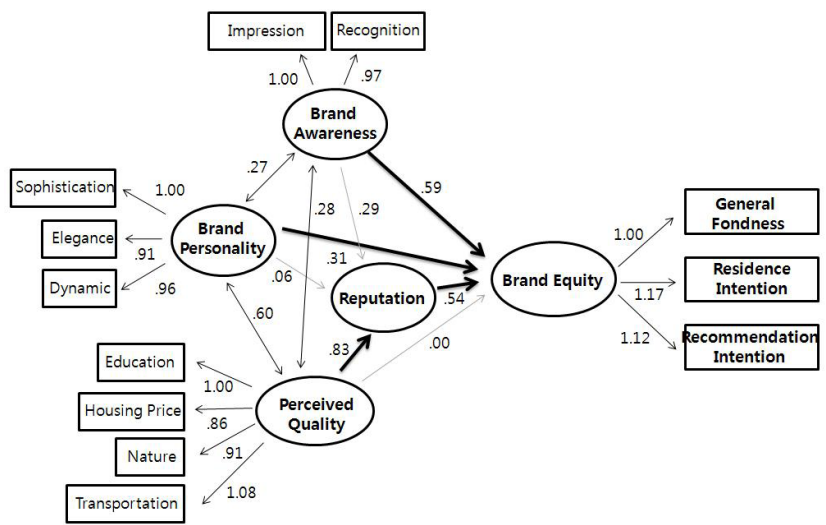

Fig.2. The Model for the Measurement of Residential Area Brand Equity

Table 6. Results of the Confirmative Factor Analysis

\begin{tabular}{c|c|c|c|c|c|c}
\hline & $\mathrm{x}$ & $\mathrm{p}$ & GFI & AGFI & RMR & NFI \\
\hline Brand personality & 368.144 & 0.000 & 0.936 & 0.890 & 0.056 & 0.944 \\
\hline Perceived Quality & 724.282 & 0.000 & 0.901 & 0.847 & 0.067 & 0.929 \\
\hline Reputation & 24.827 & 0.000 & 0.985 & 0.907 & 0.036 & 0.987 \\
\hline Brand Loyalty & 75.073 & 0.000 & 0.956 & 0.737 & 0.057 & 0.972 \\
\hline
\end{tabular}


Table 7. Cause-and-Effect Relationship of the Modified Model - Analysis of the Indirect Effects

\begin{tabular}{ccccccc}
\hline Name & Path & $\begin{array}{c}\text { Path Coefficient } \\
\text { (Estimate) }\end{array}$ & $\begin{array}{c}\text { Standard Error } \\
(\text { Standardized Estimate) }\end{array}$ & C.R. (T) & $\mathrm{p}$ \\
\hline Brand Awareness & $\rightarrow$ & Reputation & 0.287 & 0.172 & 1.664 & 0.096 \\
Brand Personality $\rightarrow$ & Reputation & 0.059 & 0.096 & 0.616 & 0.538 \\
Perceived Quality $\rightarrow$ & Reputation & 0.829 & 0.101 & 8.206 & $* * *$ & 0.000 \\
\hline$* \mathrm{p}<0.1, * * \mathrm{p}<0.05, * * * \mathrm{p}<0.01$. & & & & &
\end{tabular}

\section{(1) Total brand equity}

The total brand equity scores of Bundang and Ilsan are calculated by multiplying the weights. The weights are from the conversion of the effects of individual components calculated in the second research objective, which is fully comparable with the previously standardized brand equity scores of the individual components. Based on a full score of 100 , the final brand equity score for Bundang is 58.6 and for Ilsan 56.0. This statistically significant result shows that the brand equity of Bundang is slightly higher than Ilsan by 2.6 points.

Table 8 . The Brand Equity Weight

\begin{tabular}{ccccc}
\hline Factor & $\begin{array}{c}\text { Brand } \\
\text { Awareness } \\
(\mathrm{A})\end{array}$ & $\begin{array}{c}\text { Brand } \\
\text { Personality } \\
(\mathrm{P})\end{array}$ & $\begin{array}{c}\text { Perceived } \\
\text { Quality (Q) }\end{array}$ & $\begin{array}{c}\text { Reputation } \\
(\mathrm{R})\end{array}$ \\
\hline $\begin{array}{c}\text { Direct } \\
\text { Effect }\end{array}$ & .593 & .314 & - & .543 \\
$\begin{array}{c}\text { Indirect } \\
\text { Effect }\end{array}$ & - & - & .450 & - \\
$\begin{array}{c}\text { Converted } \\
\text { Weight }(\%)\end{array}$ & $40.9(\alpha)$ & $21.5(\beta)$ & $31.2(\gamma 1)$ & $6.4(\gamma 2)$ \\
\hline
\end{tabular}

Table 9. The Final Brand Equity

\begin{tabular}{|c|c|c|c|c|c|}
\hline \multirow[b]{2}{*}{ Area } & \multicolumn{3}{|c|}{ Descriptive Statistical Values } & \multicolumn{2}{|r|}{ T-Test } \\
\hline & $\begin{array}{l}\text { No. of } \\
\text { Cases }\end{array}$ & $\begin{array}{l}\text { Brand } \\
\text { Equity } \\
\text { (points, } \\
\text { based on } \\
\text { the full } \\
\text { point of } \\
100 \text { ) }\end{array}$ & $\begin{array}{c}\text { Standard } \\
\text { Deviation }\end{array}$ & t-value & Sig. (2-tailed) \\
\hline Bundang & 512 & 58.6 & 14.7430 & \multirow{2}{*}{2.832} & \multirow{2}{*}{$.005^{* * *}$} \\
\hline Ilsan & 512 & 56.0 & 13.6043 & & \\
\hline
\end{tabular}

(2) Brand equity for each class

To analyze whether the brand equity is related to the geographical proximity of Bundang and Ilsan, the residential areas of Seoul are divided into four zones (Northwest, Northeast, Southeast, and Southwest) ${ }^{1}$. The result showed that the brand equity of Ilsan was higher in the Northwest zone and Bundang was higher in Southeast zone. The rest of the zones showed no differences. Therefore, geographical proximity is also related to the brand equity.

A difference in the brand equity of Bundang and Ilsan is also found among different income levels. Among the low-income level respondents (less than 3 million KRW per month), the brand equity of Ilsan is relatively high compared to Bundang. On the other hand, the brand equity of Bundang is higher than Ilsan for the high-income respondents (more than 5 million KRW per month).

\section{Discussion}

Recently, there is a growing interest in marketing tools for local brand equity. Conventionally, brand marketing and equity strategies are performed by the private companies that a number of previous studies focused on in this respect. However, there are only a few studies that focused on the components that can constitute the local brand equity on the community level. To build an effective local brand equity strategy, it is important to understand the cause-and-effect relationships among the related components and how the brand equity is measured. Although a great amount of literature exists for brand and equity marketing strategies, no studies have been conducted on the brand equity specific to a single residential area. Therefore, in this study, the authors established a model to measure the brand equity of a residential area. A general brand equity measurement model for products and services is used and modified according to clarification of the brand equity components and their effects.

Two new town residential areas (Bundang and Ilsan) are chosen for the analysis. An on-line survey is conducted by residents of the Seoul Metropolitan Area. Using the information and data collected by the survey, a brand equity measurement model is established. This model is then used to analyze the cause-and-effect relationships and the effects of individual brand equity components, as well as comparing the results of two study areas.

The results of this study showed that the brand awareness and brand personality have a direct effect on brand equity formation and does not have an indirect effect on reputation. The perceived quality, on the other hand, has an indirect effect on reputation, but does not have a direct effect on brand equity formation. Since the reputation is directly influenced by perceived quality and not by brand awareness and personality, it has a direct effect on brand equity formation.

Based on the results of the analysis, useful policy recommendations can be provided to enhance the local brand competitiveness. Local governments should promote their local brand awareness by organizing local festivals, events and activities. In order to improve local brand awareness, the government should employ various efforts and strategies to vitalize their 
communities and places. The attraction of more livable communities can also heighten the brand personality.

The brand equity scores of Bundang and Ilsan are measured using an established measurement model with the structural formation of residential area brand equity. The measurements of four components are converted to points, based on a full 100 point standardized score. The brand equity of the individual components is measured by applying the score weights to each component, however, arithmetic mean points are not used in the measurement. The results showed that the brand equity of Bundang is slightly higher with the score value of 58.6 compared to 56.0 in Ilsan.

This is the first study to apply brand equity in new towns. This is necessary because of the complex characteristics involved in promoting the local brand of the residential area, which requires different strategies than conventional approaches adopted by private companies. Moreover, this study provides a theoretical framework with respect to the total equity concepts of residential area brand and is not based on the satisfaction of the residents. Given its generality, the model can conveniently be adopted and administered by the agents who are responsible for the local brand of a residential area. However, due to very limited studies in Korea as well as many developing countries, the agenda for future studies can expand established models and be applied to different functional areas.

The limitation of this study is as follows: First, the analysis was not performed from the different viewpoints of how the current residents evaluate brand equity. The respondents of the survey are not the current residents but residents of Seoul who are considered as externally potential residents.

Second, the limited reality of the interpretation of the result of the study areas is only based on two areas (Bundang and Ilsan). A more interesting result could be obtained if such study is conducted with a number of new towns based on various criteria, such as 'the six major metropolitan cities,' 'the second-stage of a new town, or 'adjacent competing cities.'

Third, the relationships with external quantitative indices that constitute a residential environment, such as the housing price, number of houses, and the infrastructure, should be analyzed in addition to the questionnaire survey results. The current method is acceptable if the perceived quality of the residential environment is consistent with the objective quality. However, underestimation or an incorrect perception of the quality implies that the administration or management of the marketing resources is not efficient. Thus, it is very important to develop methods to identify the difference between the questionnaire result and actual quantitative indices so that the equity is perceived correctly.

It is anticipated that this study can be useful in establishing specific improvement methods if future research is extended not only into the area of quantitative evaluations but also to the area of qualitative investigations. In such case, the causes implied in the evaluation results can be clearly determined.

\section{Note}

Southwest zone (Yangcheon-gu, Gangseo-gu, Guro-gu, Geumcheon-gu, Youngdeungpo-gu, Dongjak-gu, Gwanak$\mathrm{gu}$ ), Southeast zone (Gangdong-gu, Seocho-gu, Kangnam-gu, Songpa-gu), Northwest zone (Jongro-gu, Jung-gu, Yongsan-gu, Seodaemun-gu, Eunpyoung-gu, Mapo-gu) and Northeast zone (the rest).

\section{References}

1) Byeon, J. S. (2009) An Analysis of Korea Cities' Strategy on City Images and City Brand Slogans, Journal of Korea Planners Association, 44 (2), pp.105-121.

2) Jung, S.Y et al. (2009) A Study on Influencing Apartment Price with the Top 10 Apartment Brands in Seoul, Korea, Journal of Korean Urban Management Association, 22(3), pp.133-156.

3) Kang, S. K. (2006) A Study on Brand Management Model in Urban Area. Doctoral Dissertation, Seogang University, Korea.

4) Kim, J.H. (2006) Brand Asset Management, Seoul: Communication Books.

5) Lee, M .S. (2006) A Study on Apartment Brand Equity: The Effect of Apartment Brand Equity Factors on Premium Price, Doctoral Dissertation, Sunggyungwan University, Korea.

6) Kim, N. J. (2005) A Study on the Elements of City Brand Image and Influences, Journal of Korea Planners Association, 40(6), pp.177-192.

7) Gyoungnam Development Institute. (2005) A Study of the Sense of Living in Gyoungam Metropolitan Area.

8) Oh, D. H. and Lee, J. S. (2005) A Study on Scheme Activating Seoul City Marketing by Cultural Heritage Approach, Journal of Korea Planners Association, 40 (7), pp.197-211.

9) Han, J. K., Lim, K. S. and Han, M. J. (2003) The Local Brand Development Strategies on the Basis of Local Residence Perception: The Case of Gyeonggi Province, Journal of Korean Regional Development Association, 15(1), pp.71-86.

10) Pagourtzi, E., Assimakopoulos, V., Hatzichristos, T., and French, N. (2003) Real Estate Appraisal: A Review of Valuation Methods. Journal of Property Invest. Finance 21, pp.383-401.

11) Boyle, M. A. and Kiel, K. A. (2001). A Survey of House Price Hedonic Studies of the Impact of Environmental Externalities. Journal of Real Estate Literature. 9, pp.117-144.

12) Gyeonggi Research Institute. (2001) A Study of the Evaluation of the Urban Development in the Metropolitan Area and the Future Policy for Gyonggi.

13) Yoo, B. H. and Donthu, N. (2001) Developing and Validating Multidimensional Consumer-based Brand Equity Scale. Journal of Business Research, 52(1), pp.1-14.

14) Yoo, B. H., Donthu, N. and Lee, S. (2000) An Examination of Selected Marketing Mix Elements and Brand Equity, Journal of the Academy of Marketing Science, 28(April), pp.195-211.

15) Aaker, D. A. (1996 a) Measuring Brand Equity across Products and Market. California Management Review, 38 (3), pp.102-120.

16) Aaker, D. A. (1996 b) Strategic Market Management. New York: The Free Press.

17) Keller, K. L. (1993) Conceptualizing, Measuring and Managing Customer-Based Brand Equity. Journal of Marketing, 57(January), pp.1-22.

18) Simon, C. J. and Sullivan, M. W. (1992) A Financial Approach to Estimating Firm-level Brand Equity and Measuring the Impact of Marketing Events. Report Number 92-116, Marketing Science Institute, Cambridge, MA.

19) Aaker, D. A (1991), Management Brand Equity: Capitalizing on the Value of a Brand Name. New York: The Free Press.

20) Farquhar, P. H., Han, J. Y. and Ijiri, Y. (1991) Recognizing and Measuring Brand Assets. Report Number 91-119, Marketing Science Institute, Cambridge, MA.

21) Palmquist, R.B. (1991) Hedonic Methods in Measuring the Demand for Environmental Quality. North-Holland, Amsterdam.

22) Gutman, R. (1973) Building Evaluation, User Satisfaction and Design. New Jersey: Research Center for Urban and Environmental Planning, School of Architecture and Urban Planning, Princeton University. 